who, after suffering for some days from occasional romiting, (she did not know how long,) applied to a medical man, who on examination found that the integument had sloughed, and there was oozing of faculent matter. In a few days she was seen by $\mathrm{Mr}$. Chesman, who found the parts much in the same state. After a confinement of several weeks, the external opering healed, and the woman recovered without having an artificial anus, and was enabled to go back to service.

The interest of this case was in the fact of strangulation going on to such an extent as to produce sloughing, without causing such symptoms as to require surgical aid before it had reached that point; and in the fact of the intestine having healed without leaving an artiflcial opening:

\section{OPERATIONS UNDER THE INFLUENCE OF ETHER.}

Mr. Thomas then detailed the particulars of three operations which he had that morning performed at the Infirmary, in which he had used the rapour of ather by means of an apparatus made by Messrs. Horne and Co., of Newgate-street, London.

The first was amputation of the leg abore the knee of a boy, aged nine. The æther acted in two minutes, aud the patient declared he had suffered no pain, and did not awake until all was over. The second was the removal of a portion of the upper jaw of a man, aged 38 , the consequence of a malignant tumour. The æther operated in thiree or four minutes. He was not aware of the first incision, but soon became sensible, and was conscious of many things which passed, but did not give evidence of being in much suffering. The third was for harelip, in a girl aged 16, who was overpowered in three minutes, and stated that the first thing she was sensible of was the passing of the pins.

\section{APPEAL TO THE MEDICAL PROFESSION} THROUGHOUT THE KINGDOM ON THE “GENERAL MEDICAL ANNUITY FUND."

Gentlemen,-The project for establishing a "General Medical Annuity Fund," for disabled members of the profession, and for widows and orphans, has now been nearly two years before the public. It is true that in the first instance it was designed to form an integral part of the affuirs of the "Provincial Medical and Surgical Associatiun," but the meeting at Norwich having decided that it should stand alone, a separate and distinct Institution from that body, it now becomes necessary to reorganize it, and give its independent existence that permanence and stability which its value and importance demands.

The unexpected decision of the Norwich meeting somewhat staggered we, for I had previously felt I was acting under the auspices of the Provincial Associa. tion, and that many members of that important body had not oaly lent their powerful names to the Institu3tion, but had aided its adrancement by donations and subscriptions. Still, thongh I was staggered, I was not paralysed in my energien, nor disheartemed as to tho final accomplishment of the project, even though it stood alone; for that which possesses in itself an intrinsic virtue, seldom requires foreign aid to sustain it. The human heart, although corrupted by selfishness, and deadened by apathy, has many soft and gentle impulses, which need but the right stimulus to excite into activity, and when excited, a freshness and beauty is given to character, superior to renovated bodily vigour, after the wastings of disease; for "true philanthropy is health of soul."

Although the motives which have impelled mo in all I have done in this matter are open to God, and $I$ trust unimpeached by man, I have, nevertheless, felt a delicacy in obtruding myself,-an unwillingness to seem too prominent, - a desire that that which was of general interest to the profession, should find amongst its ranks others who would step forward and bear with me the heat and the toil. I thought if the project was worthy of support, the acknowledged talent of an enlightened profession like ours would be employed in its behalf, and expected, ere this, to have found many advocates; nor have I been altogether disappointed. Mr. Kelson, of Sevenoaks, Kent, has furnished to the Provincial Journal a letter, which evinces an enthusiasm worthy his benevolent spirit, and an activity in a pecuniary point of view, which is an unequivocal earnest of his sincerity. If every county in the kingdom would produce a spirit like his, the prosperity of the Institution could not be problematical. My thanks are likewise due to those gentlemen who honoured me with an answer to a circular, published a few weeks back. They have with much kindness encouraged my efforts,-expressed a confidence which is cheering, and, moreover, have promised active co-operation, so soon as they shall be put into a position to become active. This latter promise is more congenial and satisfactory to $\mathrm{my}$ mind than all the compliments they have been good enough to pay me, for I feel that counsel and help are essential. It is a gigantic establishment which is contemplated, - a vast Institution, comprebending in its grasp a huge tract of territory, and having for its object a diffusive spirit of benevolence. I therefore trust that many of these gentlemen will give to us their personal presence, at the forthcoming meeting at Northampton; it is worth while in such a cause to make some sacrifice. I am informed, both by the public press and by private letters, that the "General Medical Annuity Fund" has many well wishers, who are at present unknown as its supporters. These gentlemen are in abeyance, waiting the further development of the scheme, and its final establishment, ere they give to it their countenance and support. To such I would remark, "If you think well of the scheme, why besitate to support it? Your help is most needed now, in the early stages of its establishment, when your opinions and your counsel might lead to valuable results. The growth of a tree depends upon the planting: if the labnurers fail to loosen the earth, to arrange the fibres, to seek congenial soil and proper locality,-if they neglect to watch and water it, to shelter it from the rude blast, and sustain its 
delicate and yielding form from the rough winds which blow upon it, the chances are that it perishes; hut if, on the contrary, they combine their powers and unite their skill, in all that be necessary for its sustenance, then shall it take deep root in the earth, rear its majestic form, thicken its bole, and spread around its branches, while its impervious foliage shall shelter from heat and storm, and beneath which they may repose in calm security.

To adrance the interests of medical science is a duty we all owe both to the public and ourselves. Towatch over the political movements which bear npon our profession, more particularly at a time like the present, so rife with such movements, is equally important; but let not the claims of philanthropy and benerolence be lost in the struggle. Let their still small voice be heard; they speak to the heart, and it should feel it. In this age of general improvement, when the spirit of amelioration is abroad, and societies are established to meet the contingencies of disease and death, and the calamities which accompany soch visitations; when the artisan, the mechanic, nay, the agricultural labourer, have combined to furnish help to their distressed brother, and to the bereaved families of their departed fellowworkmen ;-can it be endured, that we, who claim for ourselves the advantages of education, the privilege of expanded minds, the influence of moral and religious feelings, and in some measure the pride of clanshipcan it be endured, that in pure benerolence and nobleness of spirit, we should be outdone by these? Does the cause of the widow and orphan require either eloquence or talent to plead with enlightened men? Is not the certainty of their fallen condition, when shrouded with poverty and neglect,-oftentimes their utter helplessness, their agony, their privations, elo. quence itself? Cannot imagination picture how forlorn and miserable must be that object who, haring once enjoyed esse, comfort, and competency, is, from no fault of her own, but from the dispensations of Heaven, thrust from her home and her pleasures to toil for bread, to sink into dependence, or to have her weekly dole from the hands of a parish functionary? It is rank hypocrisy to put a prayer to Almighty God in the venerable ritual of our church, asking Him " to defend the fatherless children and widows," while we refuse a small mite from our resources to make the prayer effectual, as far as human means can make it.

The difficulties under which many worthy and intelligent practitioners labour in a pecuniary point of view, render assurance upon their lives often impossible, but admit that a prudent and carefal man has paid from his yearly income sufficient to guarantee to his widow a thousand pounds. Now, what is the interest she will receive from this amount? Unless she adopts some speculative mode of investment, (which is always dangerous,) or to obtain large interest, gets security, uncertain as to punctuality of payment, her income from the ordinary funds of the country will scarcely afford a very humble maintenance for herself; but if she hare a family, it is obvious she must herself labour to obtain any respectable position, and it may be she is utterly unqualified for such labour. The capital must not be touched, for that capital is designed for ulterior purposes, to place her children in suitable situations, and to enable them in the end to embark in business on their own account. Now, to meet such cases, is the great object and design of the directors of the "General Medical Annuity Fund." An annuity, accruing from such a co-operative institution, would place the widow in a position of comparative independence; but when the average calculation of mortality amongst medical men, as proved by statistical returns, is compared with other professions, the lowest on the scale, the inference is fair that many die before they can have had time to make provision of any kind.

Take the following fact as an example:- $A$ young physician, respected for his general demeanour, and honoured for his talents, possessing public appoint. ments, with every prospect of obtaining extensive practice, died after a short illness, (a few minutes only,) at the early age of 36 , leaving a widow and five children TotalLY unprovided for." I quote this passage from my esteemed correspondent, to show that I have not drawn my pictures from imagination, but trusted the detail of facts.

The proposition for a "General Medical Annuity Fund" has occupied the consideration of wiser heads than mine. Dr. Percival, in his "Medical Ethies," more than forty years ago, threw out the suggestion, but no one appeared to act upon it. I have quoted the passage in former communications to medical periodicals, but it will bear reiteration. "In the county of Norfolk, and in the city of London, benevolent institutions have been lately formed for providing funds to relieve the widows and children of apothecaries, and occasionally also members of the profession who become indigent. Such schemes merit the sanction and encouragement of every liberal physician and gurgeon, and were they extended, their usefulness would be greatly increased, and their permanency almost with certainty secured. Medical subscribers from every part of Great Britain should be admitted, if they offer satisfactory testimonials of their qualifications. One comprehensire establishment seems to be more eligible than many on a smaller scale, for it would be conducted with superior dignity, regularity, and efficiency ;-With fewer obstacles from interest, prejudice, or riralship ;with considerable saving in the aggregate of time, trouble, and expense;-with more accuracy in the calculations relative to its fund;-and, consequently, with the utmost practicable extension of its dividends." *

Some gentlemen have thought a guinea a year aub. seription would be inadequate to accomplish the object we design. It is scarcely necessary to enter again into this question, for I have met it on many occasions. A guinea a year subscription will enable us to fulfil the engagements to which we pledged ourselves; $t$ and should the Institution meet with the patronage it deserves, it will do much more, because the liberal and the kind-hearted of the profession will not confine themselves in their philanthropy-we have already

- "Medical Ethics," p. 359. Edition 1827.

† See "Address," \&c., published by Churchill, p. 9. 
had examples of this fact-nor will the public, when it is properly represented to them, withhold their assistance in furthering so exemplary an object. If our anticipations in these particulars be realized, we may fairly hold out the prospect of better annuities.

It has been stated too, publicly, that there is an objection in sending money to Northampton, and that making application for annuities there, would be in. convenient; but what is the consequence of locality to a "General Medical Annuity Fund," provided the parties who controlled it are men of integrity and honour, and provided the representative system was fully carried out? It will be our great aim to neutralize all objections of this nature. When the project was first mooted, it was done at the annual meeting of the Provitcial Association, held at Sheffield; it was receired there without 'a dissenting voice, and a committee for carrying out the scheme was appointed upon the spot. The retiring president of that Association, Dr. Robertson, of Northampton, kindly accepted the office of treasurer, while the directors were all gentlemen chosen for their high standing in the profession, and their known integrity. For my own part, I took the office of Honorary Managing Director, only as an earnest of my zeal, devoting to the cause my time, and the small measure of ability I might possess, being, in short, willing to "spend and be spent" in the noble nndertaking. But the institution is now a citizen of the empire, and is ready to take up its abode where it has the best chance of support. I am willing at any moment to yield the feeble protection I have given it to any more efficient guardianship; nor do I believe an objection would be raised by my col. leagues to placing it in a position of greater advantage than we may possess. Our object is the final establishment of the "Fund," and we care not who are the parties who shall develop its energies, and spread abroad its usefalness.

The medical profession throughout the kingdom are especially invited to the consideration of this subject. Honorary local secretaries are required in the different counties and districts for furthering the scheme, and we shall esteem it an especial farour if gentlemen will accept the office voluntarily, - that is, will offer their services, rather than wait for an application. Oh! let them remember the greatness of the cause, and the glory of its achierement, and methinks they will not lack in their zeal.

In the early part of the spring, a meeting of the subscribers will be held at Northampton, of which due notice will be given by advertisement in this Journal. In these times of rapid travelling, when railway communication puts distance at defiance, we earnestly hope that many gentlemen will sacrifice to us their time and services on this interesting occasion. A noble superstructure is about to be raised, the foundations of which are love, in its best and purest acceptation, while its hallowed cement is co-operative philanthropy, upon which the blessing of God shall rest, for Cod will not withhold his blessing, when men " Hear the cry of the orphan, and wipe tears from the widow's өyes."
Gentlemen who are desirous to be present at this meeting, will confer a favour if they will apprize either Dr. Robertson or myself of their intention.

I have the honour to be, Gentlemen,

Your obedient serrant, EDWARD DANIELL,

Newport Pagnell, Bucks, Managing Director. March 1, 1847.

\section{REMARKS ON THE CASE OF ATHER-INHA- LATION AT THE ESSEX AND COLCHESTER HOSPITAL.}

TO THE EDITOR OF THE PROVINCIAL MEDICAL AND

Sir,

SURGICAL JOURNAL.

I enclose a few remarks on the late case of lithotomy at our Hospital, as it seems to me that the statement of the case has produced an impression that the immediate cause of death was apoplexy or compression of the brain.

As the æther was exhibited by me, and as I was particularly observant of its effects, and being of opinion the symptoms that attended the inhaling do not bear out such impression, and that the post-mortem appearances do not establish Mr. Beckingsale's inference, that " compression of the brain" resulted, I request your insertion of the accompanying observations, and am,

\section{Sir, faithfully yours, \\ EDWARD WILLIAMS, M.D.}

Senior Physician to the Essex and Colchester Hospital.

The æther was inhaled, mixed with a free current of atmospheric air; the mouth-piece of the apparatus, Weiss's, did not completely cover the mouth 80 as altogether to preclude the external atmosphere; hence the inbaling process was the longer in producing insensibility.

In no stage of the inhaling process was there lividity of countenance so marked as to excite apprehension of cerebral pressure; the aspect was rather characteristic of one in a state of syncope; the pupils were not dilated, and the stertorous breathing was considered by me at the time to proceed from relaxation of the uvula, and from the nostrils being compressed 80 as to prevent inspiring through them. This view was corroborated by the fact, that on removing the pressure from the nostrils, and on suspending, for a short period, the inhaling process, the stertor or snoring then ceased.

Before the patient was removed from the operating table consciousness returned, and be answered questions put to him relative to his feelings; neither was there observable paralysis, or other symptom of cerebral pressure, from the period of the operation till his death, being sensible to the last.

At the consultation of the Medical Staff, the singularly indistinct action of the heart was remarked. This, with the general prostration, decided us in re: commending stimuli and a turpentine injection."

After death the heart was, comparatively speaking, 